\title{
Thirty-three Years of Synthetic Organic Chemistry in Geneva: Reminiscences
}

\author{
Roger L. Snowden*
}

\author{
Dedicated to my wife Jackie, and my two sons David and Grégory
}

\begin{abstract}
After thirty-three years of synthetic organic chemistry research in Geneva, three years as a postdoc at the Université de Genève and over thirty years working at Firmenich, a world-renowned flavour and fragrance company, Dr. Roger L. Snowden, Vice President Synthesis, Corporate R\&D Division, Firmenich retraces his career back to 1975 when he arrived in Switzerland. A brief autobiographical sketch of this British national is presented, together with the reasons why Geneva turned out to be where he was to effect the major part of his scientific career.
\end{abstract}

Keywords: Firmenich · Flavour · Fragrance · Synthesis · University of Geneva

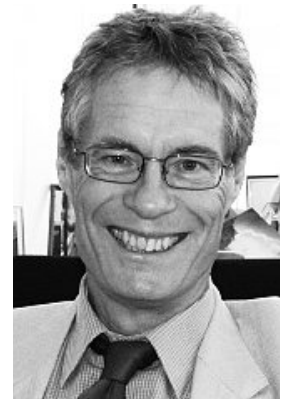

I arrived in Switzerland by car on Saturday 1st November 1975, driving over the Col de la Faucille from Dijon, all my possessions crammed into a skyblue Volkswagen 'Beetle'. The view was spectacular: a clear view of Lac Léman far below, framed by distant snow-capped mountains. This was not my first visit to Switzerland, as I had been there on two skiing trips as a schoolboy in the 1960s. Now, at the age of twenty six, I was to work and live in a country which was very different from the England I was leaving behind.

I grew up in Hartford, a small village in the county of Cheshire, where my father worked as a Production Chemist for Imperial Chemicals Industry (ICI), then one of the largest chemical companies in the world. Following in the footsteps of my two older brothers, my secondary educa-

\footnotetext{
${ }^{\star}$ Correspondence: Dr. R. L. Snowden

Firmenich SA

Corporate R\&D Division

P.O. Box 239

$\mathrm{CH}-1211$ Genève 8

Tel.: +4122780 3608

Fax: +412278033 34

E-mail: roger.snowden@firmenich.com
}

tion was at the King's School Chester, and from there, in 1967, I went on to Oxford to read chemistry. My Honours degree was followed with a D.Phil. in the same university under the supervision of Denis Meakins, and in 1973 I moved to Cambridge, where I spent two years working as a postdoc with Ian Fleming, then an Assistant Director of Research.

Why had I chosen to work in Switzerland? After completing my doctorate, my not very clearly defined ambition had been to find a university faculty position in the UK. However, in the mid-1970s the British economy was in deep recession following the first oil crisis. There were few openings in academia for young scientists such as myself, and it was for this reason that I decided to look for a second postdoctoral position, and this time I wanted to go abroad. I needed a change. During 1975, two excellent opportunities presented themselves. One was working with Dave Evans, a young American professor at Caltech in Pasadena, who already enjoyed an impressive reputation in synthetic organic chemistry. The other was working for Wolfgang Oppolzer, an upcoming talent who, after seven years working at Sandoz in Basel on heterocyclic nitrogen compounds, had arrived at the University of Geneva in 1974. Several reasons quite unrelated to chemistry made me select Geneva. First of all this was my golden chance to learn the French language. As a teenager I had spent memorable summer holidays with a family in the North of France, and ever since I had wanted to live in a French-speaking part of the world. Secondly, I would not be too far away from my family and friends in the UK, and, to be honest, the attractive proximity to the Alps and the attendant possibilities of winter skiing played a

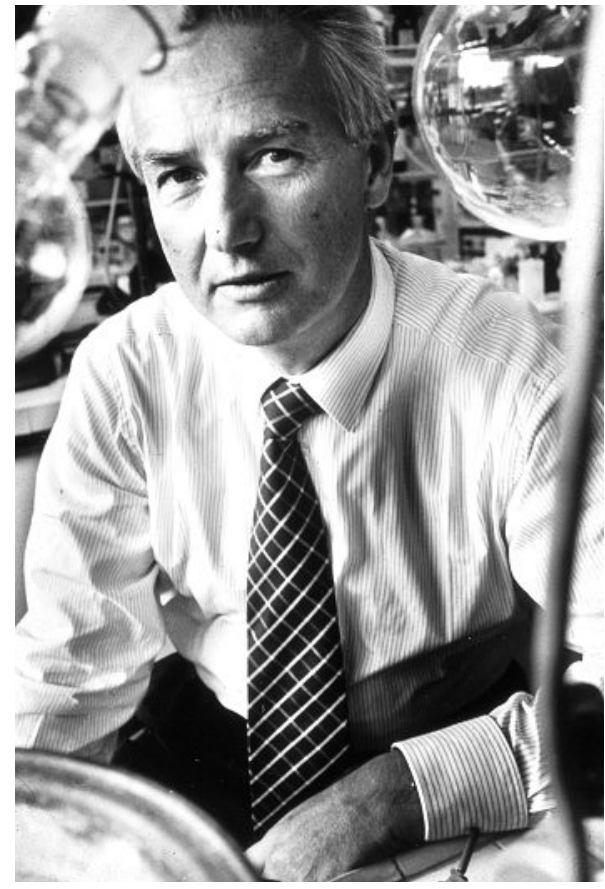

Wolfgang Oppolzer (1937-1996)

role in my decision. As chance would have it, Ian had already met Wolfgang, at Harvard in 1963-4 where both had worked as postdocs, the former for $R$. B. Woodward and the latter for $E$. J. Corey. Ian was well aware of Wolfgang's pioneering research on the use of intramolecular cycloadditions in synthesis and encouraged me to join his group. An interesting coincidence, and one which I have only recently become aware of, is that both Ian and Wolfgang share the same birthday: 4th August!

I started work at Sciences II, Département de Chimie, 30 Quai Ernest-Ansermet on Monday, 3rd November 1975, where 
I was employed as Maître Assistant. The first few weeks in Geneva were taken up with unavoidable administrative tasks, and I was often to be seen walking over to the nearby Boulevard Carl-Vogt, trying out my halting French on the unsuspecting staff of the Contrôle de l'Habitant. During this period I was greatly helped by the friendly research team of Professor Oppolzer, and more especially by his dynamic personal assistant Jacqueline (Jackie) Millaud. Despite the fact that her foot was in a plaster, it was she who helped me the most, and also she who made all the arrangements for me to rent a groundfloor apartment in a villa overlooking the lake at Crans-prèsCéligny. Less than two years later, in August 1977, Jackie was to become Jackie Snowden, our marriage taking place in her native French town of Bourgoin-Jallieu, a two-hour drive due south of Geneva.

I stayed almost three years in Wolfgang's research group, and during this time learned a lot from a very brilliant and ambitious synthetic chemist. His life was chemistry, but he had a passion for the mountains and outdoor sports, and also a love for opera and classical music. He died tragically in 1996 at the age of 58, and the loss to organic chemistry was immense. One of the highlights of my collaboration with Wolfgang was the total synthesis of norpatchoulenol, a minor constituent of patchouli oil then considered to be an active principle of the essential oil. The key step of the synthesis involved the intramolecular Diels-Alder (IMDA) reaction of an intermediate constructed using a specifically developed silicon-containing synthon (Scheme 1). ${ }^{[1]}$ Interestingly, earlier work from a research group at Firmenich, my future employer, had used an analogous approach to synthesise patchoulol, the major component of the natural oil.[2]

In the late 1970 s the scientific community in Geneva was more closely knit than nowadays, and there was a friendly contact between the Département de Chimie and the Firmenich Research Division on the other side of the River Arve. Then as now, Firmenich scientists attended conferences at Sciences II and vice versa. Quite by chance I had also become acquainted with two younger members of the Firmenich family, Bernard and Marie-Christine, who

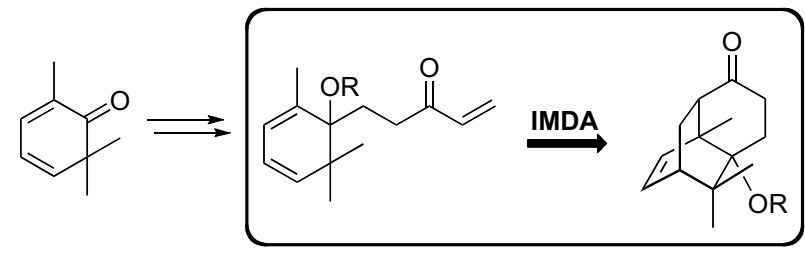

Scheme 1.

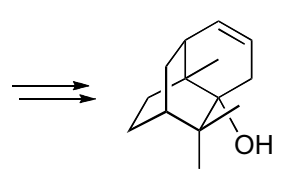

norpatchoulenol

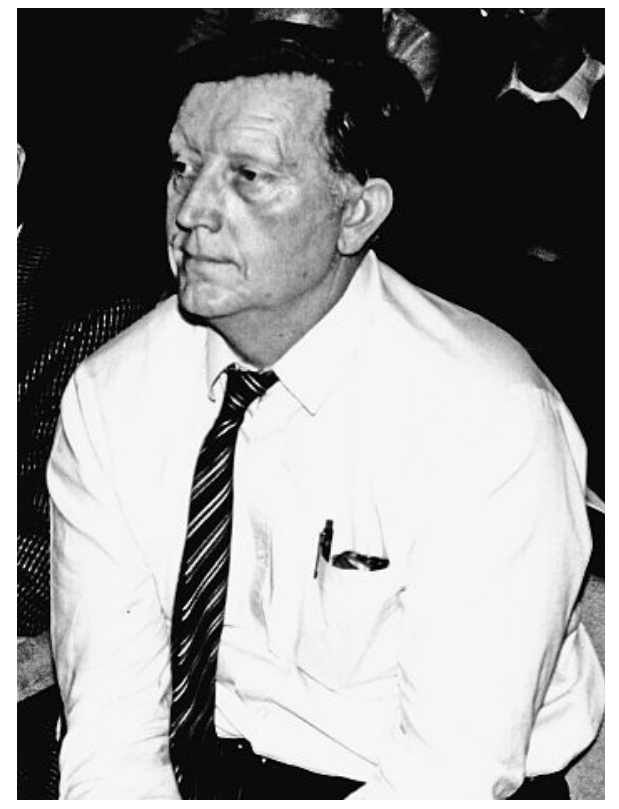

Karl Heinrich Schulte-Elte (1929-2007)

were chemistry students at the University. However, it was a real surprise when, early in 1978, Günther Ohloff, Research Director at Firmenich, offered me the possibility of joining Firmenich as a research chemist. I was tremendously flattered by this offer, but, at that time, Wolfgang was planning an extended conference tour in the USA and wanted me to stay on at the University, to manage his group in his absence and also to replace him for the teaching of several undergraduate courses. I was keen to accept this new responsibility and, anyway, Firmenich was prepared to leave their offer open to later on in the same year. Although my former ambition to work in academia was not to be realised, I was confident that my appetite for the intellectual challenge of original research, sharpened by my stay at the University of Geneva, would be welcomed by Firmenich, whose scientists were the envy of many a topflight university, and had a world-renowned reputation in science. In addition, the Research Division had developed a wide network of contacts throughout academia and counted amongst its scientific consultants illustrious professors such as George Büchi, Richard Cookson, Albert Eschenmoser, Edgar Lederer, and, soon afterwards, George Whitesides.
I started work at Firmenich, at La Plaine, on Monday 2nd October 1978.

Most of the Firmenich research laboratories were located at La Jonction, near the centre of Geneva, but there was also a process development group at La Plaine within the production site, on the banks of the River Rhône $15 \mathrm{~km}$ further south. This was the Laboratoire d'Etudes de Procédés (LEP) directed by Karl Heinrich SchulteElte. Karl Heinrich, who had arrived at Firmenich from Germany in 1963, had been Ohloff's righthand man for the past fifteen years, and his wide experience and imaginative skills in organic chemistry had resulted in not only the discovery of many new fragrance ingredients, but also the development of innovative synthetic methodology and processes for their industrialisation. He was a pillar of knowledge with an encyclopedic memory, and it was a stimulating experience and a real pleasure to discuss chemistry with him, together with colleagues, over lunchtime coffees at La Donzelle, a local bistro, a five-minute walk from the Firmenich site.

Although I was not working directly for Schulte-Elte, my laboratory was within the LEP building, and I was very fortunate to have been in close contact with him and his group. Ohloff's management style was to give a lot of creative freedom to his scientists, and though I was soon working on projects related to Firmenich products, I was also allowed to work on my own 'bluesky' projects. One of these led to a publication in 1981 describing the total synthesis of the sesquiterpene sativene, using a novel IMDA reaction as key step ${ }^{[3]}$ (see Scheme 2).

Another publication, ${ }^{[4]}$ in 1984 , described an application of a novel synthetic methodology, the $\beta$-cleavage reaction of homoallylic alkoxides, to the total synthesis of trichodiene, another sesquiterpene (Scheme 3).

Amusingly, I was recently informed that, in the 1970s, Oppolzer had had a plan to synthesise the same molecule, but his idea had never been put into practice. [5] Throughout the 1980s and 1990s much of my research work was involved in the study of acid-mediated polyene cyclisations in which the initiating group is an alkene and the internal terminating group is an alcohol. The primary objective of this research was to provide an efficient access to $( \pm)-$ Ambrox $^{\circledR}\left(\right.$ Cetalox $\left.^{\circledR[6]}\right)$ and organoleptically active analogues. The first of a series of publications describing our results appeared in 1992[7] (Scheme 4).

After the retirement of Ohloff in 1989, Ferdinand Näf became Research Director and, following several reorganizations within the Corporate R\&D Division, I moved to La Jonction. Five years later, in 1994, Schulte-Elte also retired and I took 


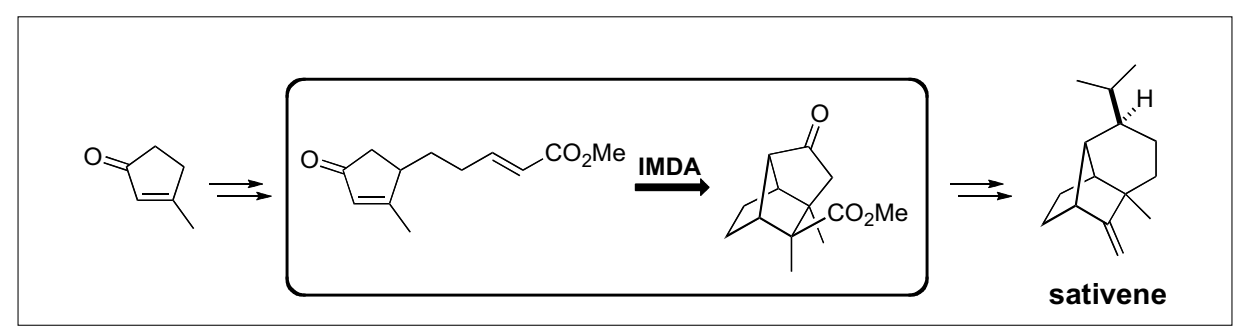

Scheme 2.

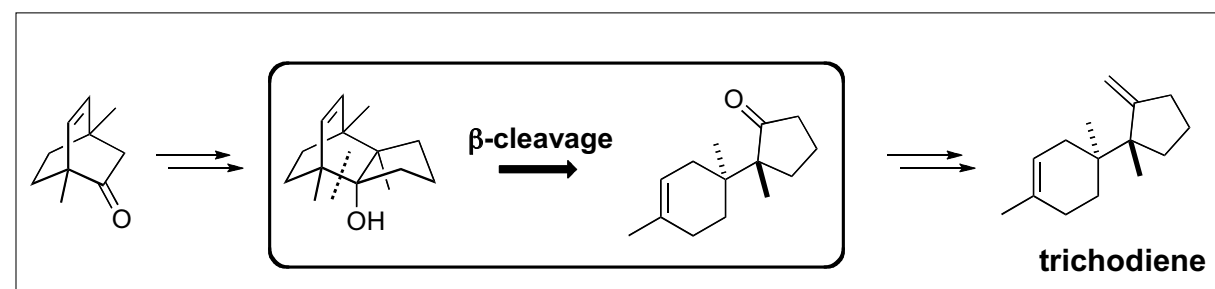

Scheme 3.

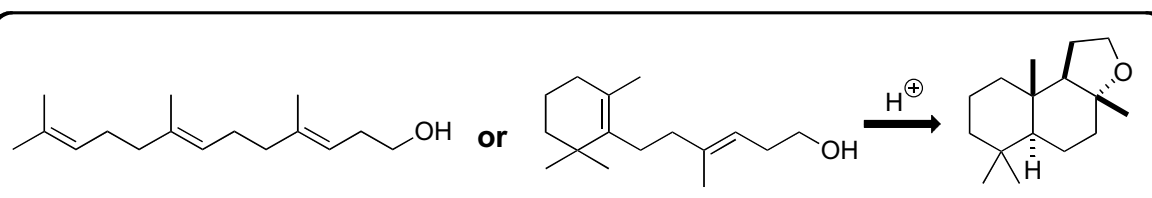

(士)-Ambrox ${ }^{\circledR}$

Scheme 4.

over the direction of his group, reporting to André Boschung, someone else who I had first met at Sciences II in the 1970s. Despite my arrival in the heady spheres of management, I have stayed close to synthetic chemistry, and that did not change when I became Vice President Synthesis in 2005, now reporting to a new Corporate Vice President R\&D, Toni Gautier. It is in the very nature of things that the forma- and whose belief in science as a key driver for commercial success remains constant.

In June 2008 I was proud and honoured to organize a Firmenich Symposium in Geneva, celebrating state of the art synthetic chemistry. Entitled FITS (Firmenich Innovation Through Synthesis), this unprecedented one and a half day event, comprising presentations from scientists within and without Firmenich, was also attended by numerous scientists from Swiss Universities. By all accounts it was a resounding success. ${ }^{[8]}$ Now in 2009, the year during which I shall be taking early retirement, I reminisce on over thirty-three years of synthetic organic chemistry research in Geneva. Three years at the University of Geneva plus thirty years at Firmenich. There is a satisfying symmetry in these numbers, and I have come to realize how much my arrival in Switzerland on that clear November day back in 1975 influenced my career and my life.

\section{Acknowledgements}

I would like to thank Catherine Gaumann and Daniel Fernandez for the preparation of the manuscript, as well as all my friends and colleagues, past and present, from the University of Geneva and Firmenich.

Received: September 23, 2009

[1] W. Oppolzer, R. L. Snowden, Tetrahedron Lett. 1978, 3505 .

[2] F. Näf, G. Ohloff, Helv. Chim. Acta 1974, 57, 1868.

[3] R. L. Snowden, Tetrahedron Lett. 1981, 22,101.

[4] R. L. Snowden, P. Sonnay, J. Org. Chem. 1984, 49, 1464.

[5] C. Fehr, personal communication.

[6] (-)-Ambrox ${ }^{\circledast}$ is a commercially important, naturally occurring ambergris odorant; the racemate is commercialized by Firmenich SA under the trade name Cetalox ${ }^{\circledR}$.

[7] R. L. Snowden, J.-C. Eichenberger, S. M. Linder, P. Sonnay, C. Vial, K. H. Schulte-Elte, J. Org. Chem. 1992, 57, 955.

[8] F. Robvieux, Chimia 2008, 62, 856. 